\title{
In memoriam Fülöp Ferenc (1952-2021)
}

\author{
SZAKONYI Zsolt* \\ Szegedi Tudományegyetem, Gyógyszertudományi Kar, Gyógyszerkémiai Intézet, 6720 Szeged, Eötvös utca 6.
}

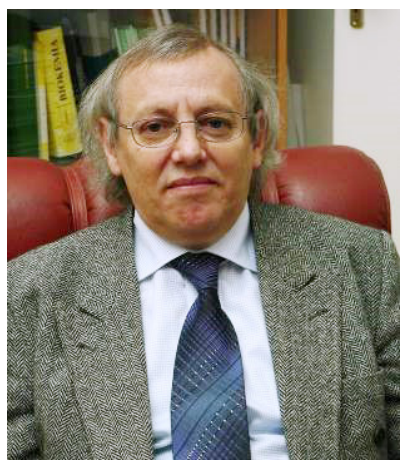

69 éves korában, 2021. július 17-én elhunyt Fülöp Ferenc, a Szegedi Tudományegyetem professzora, akadémikus, Széchenyi-díjas, és számos egyéb díjjal és kitüntetéssel elismert kémikus.

Fülöp Ferenc 1952. február 23-án született Szankon, Bács-Kiskun megyében. Kiskunfélegyházán, a Petőfi Sándor Gimnáziumban, biológia-kémia tagozaton érettségizett 1970-ben. 1975-ben a József Attila Tudományegyetem Természettudományi Kar vegyész szakán szerzett diplomát.

Először a CHINOIN Gyógyszergyár doktoranduszaként a JATE Szerves Kémiai Tanszékén (ahol 1978-ban egyetemi doktori fokozatot szerzett), majd 1980-tól a SZOTE Gyógyszerkémiai Intézet tanársegédjeként dolgozott Prof. Dr. Bernáth Gábor munkatársaként.

Kiváló kutatói és széleskörű oktatói tevékenységének köszönhetően oktatói-kutatói pályája hamar felfelé ívelt, 1983-ban adjunktusi kinevezést nyert, 1990-től docens, majd 1991-től egyetemi tanár volt. 1983-ban szerezte meg a kémiai tudomány kandidátusa, 1990-ben a kémiai tudomány doktora fokozatot. 1998-tól 2017-ig a Szegedi Tudományegyetem Gyógyszerkémiai Intézetének vezetője, 1996-1997 időszakban az SZTE Gyógyszeranalitikai Intézet, míg a 2005-2006 periódusban az SZTE Szerves Kémiai Tanszék megbízott vezetője. 2001 és 2018 között az SZTE Gyógyszertudományok Doktori Iskola vezetői tisztségét töltötte be. 1979-től a Magyar Kémikusok Egyesületének, 1980-tól a Magyar Gyógyszerészeti Társaságnak volt tagja. Az MTA Gyógyszerészeti Interdiszciplináris Bizottságának elnöke (2002-2005), míg 2006-tól két cikluson át az SZTE Gyógyszerésztudományi Kar dékánja volt.

Kutatási területe a szerves kémia, azon belül a telített heterociklusok szintézise és konformáció-vizsgálata, a gyürü-lánc tautoméria-vizsgálatok, a ciklusos béta-aminosa- vak szintézise, az önszerveződő béta-peptidek szerkezete, alkalmazásai, az enzim katalizálta kinetikus és dinamikus rezolválások, az enantioszelektív szintézisek és a felfedező gyógyszerkutatás volt. Széleskörü hazai és nemzetközi kooperációi révén azonban a szerves kémia szinte minden területén kiemelkedő publikációkat és nemzetközi szabadalmakat jegyzett.

Fülöp Ferenc kiemelkedő iskolateremtő volt, a legeredményesebb magyar szerves kémikusok között tarthatjuk számon. Közel ezer tudományos közlemény, tízezer feletti idegen hivatkozás, 54-es Hirsch-index is jelzi tudományos tevékenységének eredményességét. Több mint $50 \mathrm{PhD}$ hallgató tudományos fokozatszerzését irányította témavezetőként vagy társ-témavezetőként. Számos tanítványa lett sikeres vezető kutató, közülük napjainkig négyen, míg közvetlen munkatársai közül további hárman szereztek MTA doktora fokozatot. Számos díjat, kitüntetést kapott. A teljesség igénye nélkül néhány: MTA Zemplén Géza-díj (1983), Gábor Dénes-díj (2002), Than Károly-emlékérem (2004), Ipolyi Arnold-díj (2004), Bruckner Győző-díj (2006), Hevesy György-díj (2009), a Magyar Érdemrend tisztikeresztje (2012), Széchenyi-díj (2013), Prima díj (2019), Khwarizmi-díj (2009). 2021-ben az MTA SZAB Pro Scientia Életmüdíjjal tüntette ki.

A szintetikus szerves kémia és a gyógyszerkutatás terén kifejtett munkássága elismeréséül 2007-ben a Magyar Tudományos Akadémia levelező tagjává választotta. 2013-tól a Magyar Tudományos Akadémia rendes tagja, 2017-2020 időszakban a Kémiai Tudományok Osztályának elnöke volt. 2014-2020 között két periódusban az MTA Szegedi Területi Bizottságának elnöki tisztét is betöltötte. Tudományos és egyetemi közéleti tevékenysége mellett embersége, a természet és művészetek szeretete is példamutató volt kollégái és ismerősei számára. (Különösképpen a gombák, valamint a sztereokémiával összekapcsolható művészeti alkotások és természeti képződmények, például csigák és kagylók érdekelték).

Fülöp Ferenccel nemcsak kiváló kutató, oktató távozott közülünk, hanem jó barátunk, kollégánk, kiemelkedő müveltségű embertársunk is. Távozása hatalmas veszteség nemcsak a szegedi kémikustársadalom számára, de az egész magyar tudománynak is.

Emlékét szeretettel és tisztelettel megőrizzük!

* Tel.: +36-52-546-809; e-mail: szakonyi.zsolt@szte.hu

127. évfolyam, 2. szám, 2021. 


\section{In memoriam professor Ferenc Fülöp (1952-2021)}

Ferenc Fülöp, a professor of the University of Szeged, a member of the Hungarian Academy of Sciences, and a chemist recognized with many prizes and honors, died on $17^{\text {th }}$ July 2021, at the age of 69 .

Ferenc Fülöp was born on $23^{\text {rd }}$ February 1952 in Szank, BácsKiskun County. In 1975 he graduated at Attila József University (JATE), Faculty of Science as a chemist. He was first employed as a doctoral student in CHINOIN Pharmaceutical Company at the Department of Organic Chemistry of JATE (where he obtained a doctoral degree in 1978), and from 1980 as a teaching assistant at the University of Szeged, Faculty of Medicine, Institute of Pharmaceutical Chemistry in the team of Prof. Dr. Gábor Bernáth.

Thanks to his excellent research and teaching activities, his university career quickly curved upwards, he was appointed an assistant professor in 1983, an associate professor in 1990 and a full professor in 1991. He received his Candidate of Chemical Science degree in 1983 and the Doctor of Science (DSc) title in chemistry in 1990. From 1998 to 2017 he was the head of the Institute of Pharmaceutical Chemistry of the University of Szeged (SZTE). Beside this main function in the period of 1996-1997 he was also the head of the Institute of Pharmaceutical Analysis of SZTE, and from 2005 until 2006 the head of the Department of Organic Chemistry of SZTE, too. Between 2001 and 2018, he was the head of the Doctoral School of Pharmaceutical Sciences at SZTE. From 2006 he was the dean of the Faculty of Pharmacy of the University of Szeged for two periods.

His research interests cover several topics in organic chemistry, including the synthesis and conformational analysis of saturated heterocycles, ring-chain tautomerism studies, the synthesis of cyclic beta-amino acids, the structure and applications of self-assembling beta-peptides, enzyme-catalyzed kinetic and dynamic resolutions and enantioselective exploratory drug research.
Armed with extensive domestic and international collaborations, he gained outstanding publications and international patents in almost all fields of organic chemistry.

Professor Fülöp can be regarded as one of the most successful Hungarian organic chemists. Nearly a thousand scientific publications, more than ten thousand idependent citations, and a Hirsch index of 54 also indicate the effectiveness of his scientific activity. He supervised the works of more than $50 \mathrm{PhD}$ students very successfully. He received many awards, some of them are: Géza Zemplén Prize of the Hungarian Academy of Sciences (1983), Dénes Gábor Prize (2002), Károly Than Memorial Medal (2004), Arnold Ipolyi Prize (2004), Győző Bruckner Prize (2006), György Hevesy Award (2009), Officer's Cross of the Hungarian Order of Merit (2012), Széchenyi Award (2013), Prima Award (2019). In 2021 he was awarded the Pro Scientia Lifetime Achievement Award by the Hungarian Academy of Sciences.

He was elected a corresponding member of the Hungarian Academy of Sciences in 2007. From 2013 he was a full member of the Academy, in the period 2017-2020 he was the president of the Section of Chemical Sciences of the Academy. Between 2014 and 2020, he also served as chairman of the Szeged Regional Committee of the Hungarian Academy of Sciences. Beside his scientific and academic activities, he was an example to his colleagues and acquaintances of his humanity, his love of nature and the arts.

With Ferenc Fülöp, not only an excellent researcher and teacher left us, but also our colleague and good friend. His death is a huge loss not only for the chemical society of Szeged, but also for the entire Hungarian science.

We will preserve his memory with love and respect. 